Received $\quad 19.05 .2016$ Reviewed 13.07.2016 Accepted 27.09.2016

A - study design B - data collection

C - statistical analysis

D - data interpretation

E - manuscript preparation

F - literature search

\title{
Assessment of dam construction impact on hydrological regime changes in lowland river - A case of study: the Stare Miasto reservoir located on the Powa River
}

\author{
Mariusz SOJKA ${ }^{\text {ACDEF }}$, Joanna JASKULA ABCDEF, \\ Joanna WICHER-DYSARZ ${ }^{\text {BDEF }}$, Tomasz DYSARZ ${ }^{\text {DEF }}$
}

Poznań University of Life Sciences, Faculty of Enviromental Engineering and Landscape Planning, ul. Wojska Polskiego 28, 60-637 Poznań, Poland; e-mail: jaskula@up.poznan.pl

For citation: Sojka M., Jaskuła J., Wicher-Dysarz J., Dysarz T. 2016. Assessment of dam construction impact on hydrological regime changes in lowland river - A case of study: the Stare Miasto Reservoir located on the Powa River. Journal of Water and Land Development. No. 30 p. 119-125. DOI: 10.1515/jwld-2016-0028.

\begin{abstract}
The purpose of the presented research is analysis and assessment of the Stare Miasto reservoir impact on the hydrological regime changes of the Powa River. The reservoir was built in 2006 and is located in the central part of Poland. The total area of inundation in normal conditions is 90.68 ha and its capacity is $2.159 \mathrm{mln} \mathrm{m}^{3}$. Hydrological regime alteration of the Powa River is analysed on the basis of daily flows from the Posoka gauge station observed during period 1974-2014. Assessment of hydrological regime changes is carried out on the basis of Range of Variability Approach (RVA) method. All calculations are made by means of Indicators of Hydrologic Alteration (IHA) software version 7.1.0.10. The analysis shows that the Stare Miasto reservoir has a moderate impact on hydrological regime of the Powa River. Construction of the reservoir has positive effect on stability of minimal flows, which are important for protection of river ecosystems. The results obtained indicate that the Stare Miasto reservoir reduces a spring peak flow and enables to moderate control of floods.
\end{abstract}

Key words: hydrologic regime alteration, Indicators of Hydrologic Alteration (IHA) software, indicators of hydrologic regime, the Stare Miasto reservoir

\section{INTRODUCTION}

Dams have important impact on hydrological regime of rivers, primarily through changes in magnitude, timing and frequency of flows [GRAF 1999; 2001; Magilligan, Nislow 2001; 2005]. Constructions of reservoirs have great impact on hydrological conditions in rivers which are significantly different from the pre-dam natural flow regime. Hydrological alteration can be defined as any anthropogenic disruption in the magnitude timing and frequency of natural river flows [ROSENBERG et al. 2000].
The analyses presented in the literature show that dam construction have an impact on flow variability especially enhanced low flows and diminished high flows [TEBEKARI et al. 2012; YAN et al. 2010; ZUO, LAING 2015]. Hydrological alteration caused by flow regulation is also observed in the "shape" of flow hydrograph and flow duration curves. Ecological responses are especially related to changes in duration and timing of flows, rates of change and frequency of rises and falls [MAGILLIGAN, NiSLOW 2005; RICHTER et al. 1996]. 
Hydrological regime determines many physical and ecological aspects of aquatic, wetland and riparian ecosystems [RICHTER et al. 1996]. Hydrological conditions play a major role of geomorphic processes and ensure maintaining the function and diversity of water related habitats [MAGILLIGAN, NISLOW 2005; STANFORD, WARD 1993]. The recognition of the direction of hydrological regime alteration is necessary to develop protection and restoration plans for aquatic ecosystems downstream from the reservoirs. This is a major problem in management of regulated rivers [HARMAN, STEWARDSON 2005; LAJOIE et al. 2007; POFF, HART 2002].

One of the mainly used methods to identify the impact of dam construction on river hydrological regime is one called Indicators of Hydrologic Alteration (IHA), developed by The Nature Conservancy [FANTIN-CRUZ et al. 2015; RICHTER et al. 1996]. The basis of this method are daily flows series for period before and after dam construction. These data are mainly obtained from gauge station located downstream from the reservoir [RICHTER et al. 1996; YU et al. 2015]. The hydrological indicators used in IHA method were developed by RICHTER et al. [1996]. The indicators are divided in five major groups: (1) magnitude of monthly water conditions, (2) magnitude and duration of annual extremes, (3) timing of annual extremes, (4) frequency and duration of high and low pulses, (5) rate and frequency of water condition changes. RiCHTER et al. [1997] proposed the Range of Variability Approach (RVA) to determine hydrological regime alteration. In order to assess the degree of hydrologic alteration the target range for each indicators are calculated. To improved the interpretation the RVA results the three-class scale which indicate low, moderate and high alteration of hydrologic regime was introduced [RICHTER et al. 1998].

The main purpose of this study is the assessment of the impact of the Stare Miasto reservoir on hydrological regime alteration of Powa River. The analysis is based on data series for period before (1974-2005) and after dam construction (2006-2014).

\section{MATERIALS AND METHODS}

Hydrological regime alteration of the Powa River is analyzed on the basis of daily flows from the Posoka gauge station observed during period 19742014. The gauge station is located $10 \mathrm{~km}$ downstream of the main dam of the Stare Miasto reservoir (Fig. 1).

The changes in the hydrologic regime caused by the dam construction is assessed applying the RVA method. For this purpose in the first step the value of
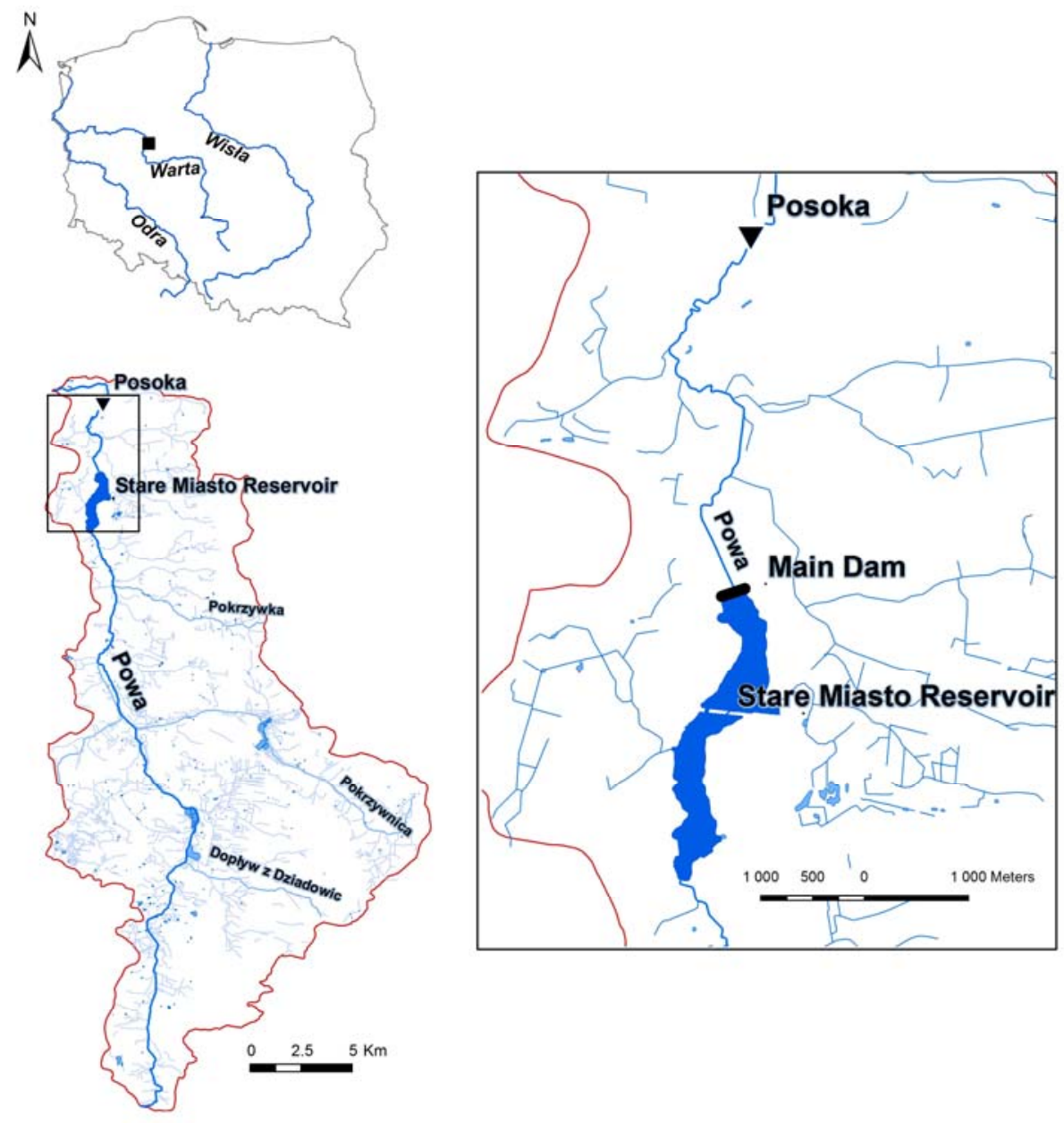

Fig. 1. Study site location; source: own study 
33 parameters for pre and post dam period are calculated based on daily flow data (Tab. 1). In the second step based on annual value for each parameter the minimum (min), maximum ( $\max$ ), medians (med), and coefficients of dispersion (CoD) are computed.
Next, target ranges in RVA method are identified by the $25^{\text {th }}$ and $75^{\text {th }}$ percentile values for each of IHA parameters. The values of target ranges are calculated based on pre-impact data observed during period 1974-2005.

Table 1. The Indicators of Hydrologic Alteration parameters

\begin{tabular}{|c|c|c|}
\hline IHA statistics group & Regime characteristics & Hydrologic parameters \\
\hline $\begin{array}{l}\text { Group 1: } \\
\text { Magnitude of monthly water conditions }\end{array}$ & $\begin{array}{l}\text { magnitude } \\
\text { timing }\end{array}$ & mean value for each calendar month \\
\hline $\begin{array}{l}\text { Group 2: } \\
\text { Magnitude and duration of annual extreme water } \\
\text { conditions }\end{array}$ & $\begin{array}{l}\text { magnitude } \\
\text { duration }\end{array}$ & $\begin{array}{l}\text { annual minima 1-day means } \\
\text { annual maxima 1-day means } \\
\text { annual minima 3-day means } \\
\text { annual maxima 3-day means } \\
\text { annual minima 7-day means } \\
\text { annual maxima 7-day means } \\
\text { annual minima 30-day means } \\
\text { annual maxima 30-day means } \\
\text { annual minima 90-day means } \\
\text { annual maxima 90-day means } \\
\text { number of zero-flow days } \\
\text { base flow index: 7-day minimum flow/mean flow for year }\end{array}$ \\
\hline $\begin{array}{l}\text { Group 3: } \\
\text { Timing of annual extreme water conditions }\end{array}$ & timing & $\begin{array}{l}\text { Julian date of each annual } 1 \text { day maximum } \\
\text { Julian date of each annual 1-day minimum }\end{array}$ \\
\hline $\begin{array}{l}\text { Group 4: } \\
\text { Frequency and duration of high and low pulses }\end{array}$ & $\begin{array}{l}\text { magnitude } \\
\text { frequency } \\
\text { duration }\end{array}$ & $\begin{array}{l}\text { number of low pulses within each water year } \\
\text { mean or median duration of low pulses (days) } \\
\text { number of high pulses within each water year } \\
\text { mean or median duration of high pulses (days) }\end{array}$ \\
\hline $\begin{array}{l}\text { Group 5: } \\
\text { Rate and frequency of water condition changes }\end{array}$ & $\begin{array}{l}\text { frequency } \\
\text { rate of change }\end{array}$ & $\begin{array}{l}\text { rise rates } \\
\text { fall rates } \\
\text { number of hydrologic reversals }\end{array}$ \\
\hline
\end{tabular}

Source: The Nature Conservancy [2009].

The hydrologic alteration (HA) determines the degree which the RVA target range is not attained. HA was calculated as:

$$
H A=\frac{O F-E F}{E F}
$$

where OF means observed frequency in post-impact period, EF is expected frequency. When observed frequency of post-impact annual values falling within the RVA target range equals the expected frequency, hydrologic alteration (HA) is equal to zero. Negative values indicate that values fell within the RVA boundaries less often than expected. When values of parameters fall inside the RVA boundaries more often than expected, it indicates a positive value. Subsequently, the degree of hydrologic alteration is identified in one of three classes: (1) minimal or no alteration $(|0-0.33|$ indicated by L), (2) moderate alteration $(|0.34-0.67|$ indicated by $\mathrm{M})$ or (3) high alteration $(|0.68-1.00|$ indicated by $\mathrm{H})$. The computations are performed with IHA software version 7.1.0.10 developed by The Nature Conservancy [2009].

\section{STUDY AREA}

The Stare Miasto reservoir is located on the Powa River which is a left tributary of the Warta River. The reservoir was built in 2006 . The total drainage area of the Powa River is $344.48 \mathrm{~km}^{2}$. The drainage area of the Posoka gauge station is $332 \mathrm{~km}^{2}$. The gauge station is located in $3+800 \mathrm{~km}$ of the Powa River. The total capacity of the reservoir equals $2.159 \cdot 10^{6} \mathrm{~m}^{3}$ [WOLIŃSKI, ZGRABCZYŃSKI 2008].

The Stare Miasto reservoir has a two-stage construction. The object is divided in two parts - main part and upper sedimentation zone. The main dam is located in $13+800 \mathrm{~km}$ the Powa River and it is working in the same conditions as the ordinary single-part reservoir. The second, smaller dam is located between the main part of reservoir and upper sedimentation zone. The upper part is designed to store sediment deposits and control of pollutants accumulation. Total capacity of the Stare Miasto reservoir is $0.294 \mathrm{mln} \mathrm{m}^{3}$. Main part of reservoir includes water supply capacity and flood protection capacity [DYSARZ, WICHERDYSARZ 2013]. Total capacity of this part is 1.865 $\mathrm{mln} \mathrm{m}^{3}$. The Stare Miasto is multi-purpose reservoir, it provides water for irrigation and protects city of the Konin from floods. An important role is maintaining the flows in the Powa River higher than mean annual low flow of the multi-year period. The object is also used to recreation and touristic purposes. From 2015 the water stored in reservoir is used for generation of electricity in hydro-power plant.

The reservoir works in the annual cycle. The reservoir is filled with water in March. Subsequently, the water surface level in Stare Miasto reservoir is hold on the level $93.50 \mathrm{~m}$ a.s.l. from April to September [WOLIŃSKI, ZGRABCZYŃSKI 2008]. In October the water is released from the reservoir until the water 
elevations reach minimal level $92.70 \mathrm{~m}$ a.s.l. This level is kept until the end of February.

\section{RESULTS}

On the basis of data from the Posoka gauge station collected in the period 1974-2014 it may be concluded the flow in the Powa River varies from 0.012 to $42.60 \mathrm{~m}^{3} \cdot \mathrm{s}^{-1}$. The mean annual flow is $1.20 \mathrm{~m}^{3} \cdot \mathrm{s}^{-1}$. The Powa River has strong developed nival regime, mean runoff in April exceeds the mean annual runoff by $184 \%$. The average unit outflow from the Powa River basin is $0.0035 \mathrm{~m}^{3} \cdot \mathrm{s}^{-1} \cdot \mathrm{km}^{-2}$. The average annual outflow in years $1974-2014$ equals $37.69 \cdot 10^{6} \mathrm{~m}^{3}$. The Impounded Runoff Index (IR) is calculated as the ratio of reservoir capacity and mean annual runoff. The value of IR for analyzed object is 0.46 .
The results of the RVA analysis are shown in Table 2 and Figure 2.

The analysis of HA value in the first group according to Table 2 show low and moderate degree of hydrologic alteration for most months. Median flows in December, February, March, July, August and October fall to the RVA boundaries with the same frequency in the pre- and post-dam period. Whereas a high degrees of hydrologic alternations are observed only in three months. In April and May the HA reached -0.70 and -0.75 respectively. Figure $3 \mathrm{~A}$ and $3 \mathrm{~B}$ show also that the annual median flows for April and May fall less frequently within the RVA target range after 2006, most of which are below the RVA low boundary. On the contrary in June the HA value reached 0.78 , and the monthly median flow fall most frequently within the RVA target range in the postimpact period (Fig. 3C). Additionally the coefficient of dispersion for this month is smallest.

Table 2. The Indicators of Hydrologic Alteration of the Powa River at Posoka gauge station

\begin{tabular}{|c|c|c|c|c|c|c|c|c|c|c|c|c|}
\hline \multirow[t]{2}{*}{ Parameter } & \multicolumn{4}{|c|}{$\begin{array}{c}\text { Pre-impact period: } \\
\text { 1974-2005 }\end{array}$} & \multicolumn{4}{|c|}{$\begin{array}{c}\text { Post-impact period: } \\
2006-2014\end{array}$} & \multicolumn{2}{|c|}{$\begin{array}{c}\text { RVA } \\
\text { boundaries }\end{array}$} & \multicolumn{2}{|c|}{$\begin{array}{l}\text { Hydrologic } \\
\text { alteration }\end{array}$} \\
\hline & $\min$ & med. & $\max$ & $\mathrm{CoD}$ & $\min$ & med. & $\max$ & $\mathrm{CoD}$ & low & high & value & class \\
\hline \multicolumn{13}{|c|}{ Parameter group 1} \\
\hline November & 0.28 & 0.88 & 3.47 & 1.13 & 0.61 & 1.23 & 5.70 & 0.60 & 0.71 & 1.07 & -0.41 & $\mathbf{M}$ \\
\hline December & 0.44 & 1.29 & 6.31 & 1.10 & 0.32 & 1.22 & 2.38 & 0.77 & 0.97 & 1.87 & 0.19 & $\mathbf{L}$ \\
\hline January & 0.32 & 1.20 & 3.29 & 0.88 & 0.45 & 1.11 & 2.64 & 0.93 & 0.90 & 1.55 & 0.48 & M \\
\hline February & 0.21 & 1.39 & 4.59 & 0.73 & 0.46 & 1.21 & 3.20 & 1.09 & 1.07 & 1.77 & -0.11 & $\mathbf{L}$ \\
\hline March & 0.57 & 1.74 & 9.50 & 0.80 & 0.37 & 1.64 & 2.63 & 1.03 & 1.17 & 2.33 & -0.11 & $\mathbf{L}$ \\
\hline April & 0.38 & 1.10 & 2.99 & 0.88 & 0.32 & 0.85 & 2.03 & 1.43 & 0.97 & 1.37 & -0.70 & $\mathbf{H}$ \\
\hline May & 0.10 & 0.58 & 1.72 & 0.85 & 0.18 & 0.42 & 1.51 & 1.83 & 0.46 & 0.73 & -0.75 & $\mathbf{H}$ \\
\hline June & 0.07 & 0.32 & 2.72 & 0.98 & 0.09 & 0.43 & 0.95 & 0.55 & 0.23 & 0.48 & 0.78 & $\mathbf{H}$ \\
\hline July & 0.02 & 0.25 & 4.75 & 1.34 & 0.08 & 0.28 & 0.93 & 2.09 & 0.20 & 0.37 & -0.24 & $\mathbf{L}$ \\
\hline August & 0.02 & 0.24 & 2.78 & 1.98 & 0.14 & 0.38 & 0.81 & 1.09 & 0.17 & 0.40 & 0.19 & $\mathbf{L}$ \\
\hline September & 0.06 & 0.33 & 2.66 & 1.84 & 0.17 & 0.65 & 1.54 & 0.99 & 0.19 & 0.52 & -0.41 & M \\
\hline October & 0.10 & 0.61 & 2.20 & 1.16 & 0.42 & 0.91 & 7.54 & 1.00 & 0.43 & 0.89 & -0.11 & $\mathbf{L}$ \\
\hline \multicolumn{13}{|c|}{ Parameter group 2} \\
\hline 1-day minimum & 0.01 & 0.14 & 0.50 & 0.89 & 0.06 & 0.12 & 0.24 & 0.79 & 0.11 & 0.17 & 0.19 & $\mathbf{L}$ \\
\hline 3-day minimum & 0.01 & 0.14 & 0.55 & 1.09 & 0.06 & 0.13 & 0.24 & 0.79 & 0.11 & 0.20 & 0.19 & $\mathbf{L}$ \\
\hline 7-day minimum & 0.01 & 0.15 & 0.63 & 1.15 & 0.07 & 0.13 & 0.26 & 0.77 & 0.12 & 0.21 & 0.48 & $\mathbf{M}$ \\
\hline 30-day minimum & 0.02 & 0.18 & 0.85 & 1.31 & 0.07 & 0.19 & 0.45 & 0.70 & 0.13 & 0.24 & 0.48 & $\mathbf{M}$ \\
\hline 90-day minimum & 0.03 & 0.25 & 1.36 & 1.37 & 0.11 & 0.48 & 0.67 & 0.64 & 0.16 & 0.40 & -0.41 & $\mathbf{M}$ \\
\hline 1-day maximum & 1.37 & 7.60 & 42.60 & 1.21 & 2.29 & 8.50 & 28.50 & 1.36 & 3.99 & 10.80 & 0.09 & $\mathbf{L}$ \\
\hline 3-day maximum & 1.30 & 6.32 & 33.77 & 1.42 & 2.20 & 7.67 & 20.43 & 1.33 & 3.79 & 9.22 & 0.19 & $\mathbf{L}$ \\
\hline 7-day maximum & 1.11 & 5.15 & 22.20 & 1.38 & 2.05 & 6.15 & 13.67 & 1.44 & 3.31 & 7.50 & 0.19 & $\mathbf{L}$ \\
\hline 30-day maximum & 0.76 & 2.87 & 11.27 & 0.87 & 1.41 & 3.41 & 6.94 & 1.06 & 2.33 & 4.21 & 0.19 & $\mathbf{L}$ \\
\hline 90-day maximum & 0.63 & 2.08 & 5.21 & 0.99 & 0.92 & 2.43 & 3.67 & 0.60 & 1.70 & 2.77 & 0.19 & $\mathbf{L}$ \\
\hline Base flow index & 0.02 & 0.13 & 0.37 & 0.65 & 0.07 & 0.12 & 0.25 & 0.79 & 0.11 & 0.18 & 0.19 & $\mathbf{L}$ \\
\hline \multicolumn{13}{|c|}{ Parameter group 3} \\
\hline Date of minimum & 151.0 & 212.0 & 321.0 & 0.2 & 112.0 & 206.0 & 265.0 & 0.19 & 171.9 & 234.0 & 0.37 & $\mathbf{M}$ \\
\hline Date of maximum & 1.0 & 46.0 & 366.0 & 0.2 & 25.0 & 83.0 & 329.0 & 0.33 & 37.01 & 86.99 & -0.41 & $\mathbf{M}$ \\
\hline \multicolumn{13}{|c|}{ Parameter group 4} \\
\hline Low pulse count & 0.00 & 3.00 & 14.00 & 1.00 & 1.00 & 4.00 & 9.00 & 1.50 & 2.00 & 4.11 & -0.05 & $\mathbf{L}$ \\
\hline Low pulse duration & 1.00 & 9.00 & 147.00 & 2.89 & 2.00 & 7.50 & 149.00 & 0.83 & 4.00 & 20.59 & 0.78 & $\mathbf{H}$ \\
\hline High pulse count & 0.00 & 5.00 & 16.00 & 0.80 & 6.00 & 11.00 & 18.00 & 0.77 & 4.00 & 7.00 & -0.33 & $\mathbf{L}$ \\
\hline High pulse duration & 1.00 & 7.00 & 24.50 & 1.86 & 2.00 & 4.00 & 10.00 & 1.25 & 5.00 & 13.44 & 0.09 & $\mathbf{L}$ \\
\hline \multicolumn{13}{|c|}{ Parameter group 5} \\
\hline Rise rate & 0.02 & 0.08 & 0.24 & 0.82 & 0.03 & 0.07 & 0.24 & 0.71 & 0.06 & 0.10 & 0.09 & $\mathbf{L}$ \\
\hline Fall rate & -0.22 & -0.07 & -0.02 & -0.82 & -0.25 & -0.07 & -0.03 & -1.04 & -0.10 & -0.06 & 0.19 & $\mathbf{L}$ \\
\hline Number of reversals & 49.00 & 84.00 & 133.00 & 0.35 & 71.00 & 95.00 & 119.00 & 0.17 & 72.89 & 92.11 & -0.11 & $\mathbf{L}$ \\
\hline
\end{tabular}

Explanations: RVA = Range of Variability Approach, $\mathrm{CoD}=$ coefficients of dispersion.

Source: own study. 


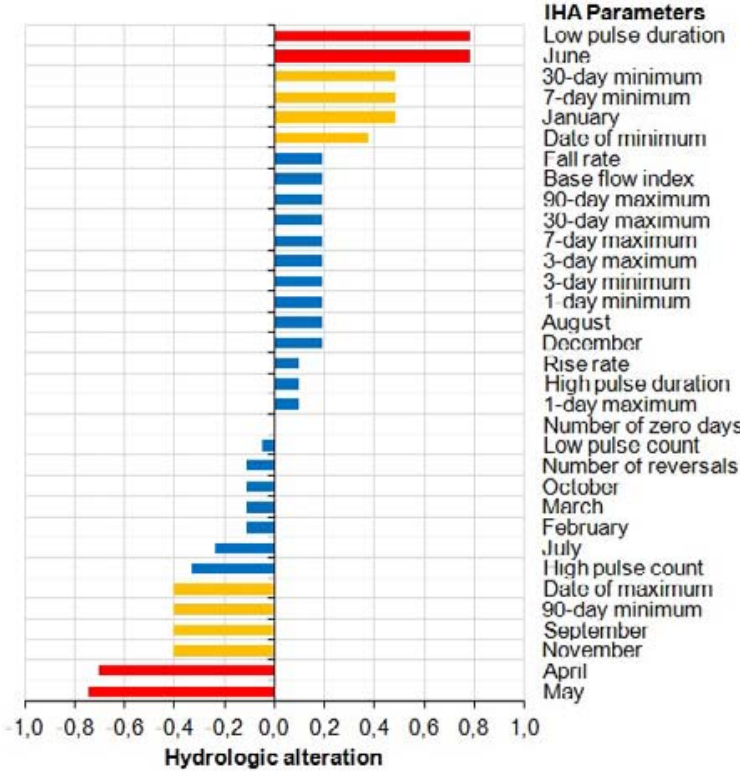

Fig. 2. Value of hydrologic alteration for 33 Indicators of Hydrologic Alteration (IHA) parameters; source: own study
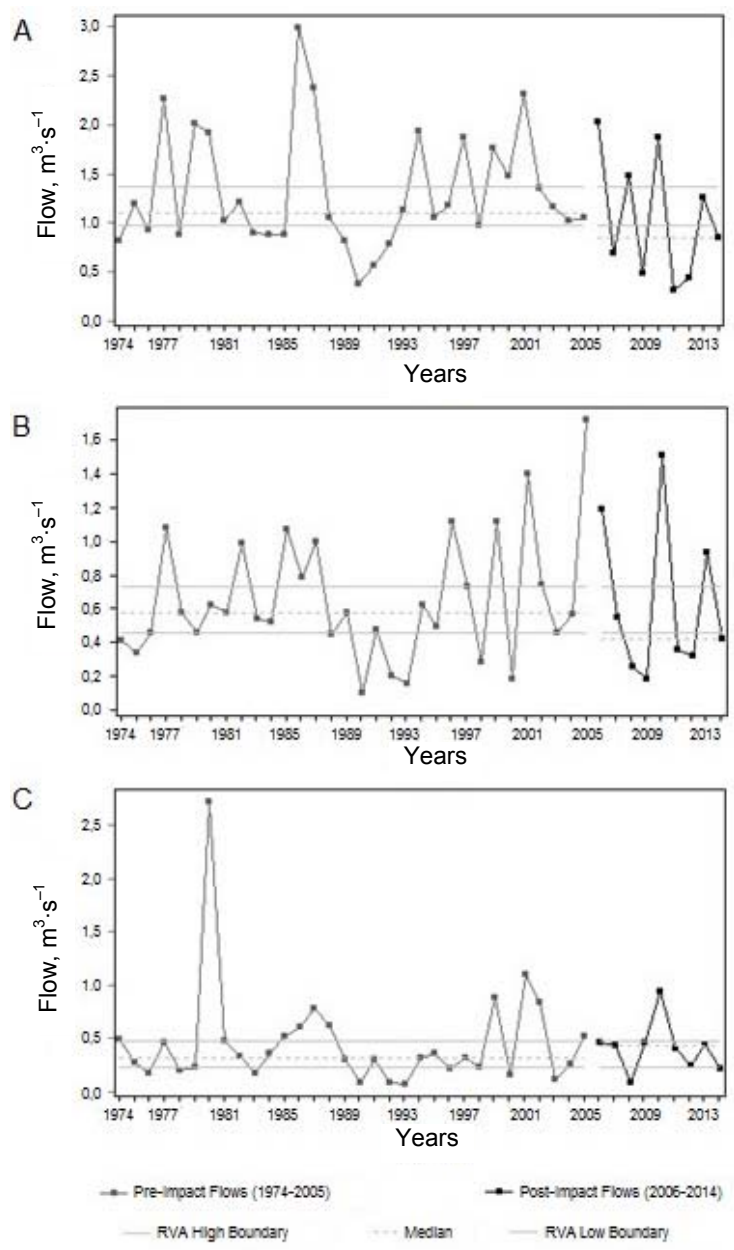

Fig. 3. Median monthly flows of the Powa River for April (A), May (B) and June (C) at the Posoka gauge station; RVA = Range of Variability Approach; source: own study
The monthly median flows from December to May in the post-impact period are lower than in the pre-impact period. Especially in April and May monthly median flow after 2006 are lower by 0.25 $\mathrm{m}^{3} \cdot \mathrm{s}^{-1}$ and $0.16 \mathrm{~m}^{3} \cdot \mathrm{s}^{-1}$, respectively. The retention of the Stare Miasto reservoir is one major reason for the reduction of river flows. However, from June to November the medians monthly flows are higher after 2006. Particularly the flows from September to November after dam construction are higher more than $0.3 \mathrm{~m}^{3} \cdot \mathrm{s}^{-1}$. This increase is mainly caused by water release of the Stare Miasto reservoir.

Differences observed in the second group of IHA parameters are non-significant. These parameters describe the magnitude and duration of annual extreme water conditions. The majority of parameters indicate the low alteration (Fig. 2). Only the 7-, 30and 90-minimum flows show moderate alteration. As shown in Table 2 the annual 7-day and 30-day minima flows at the Posoka gauge station after 2006 are on the same level in pre- and post-impact period. However they fall most frequently within the RVA target range (Fig. 4A and 4B). Both of them exhibit
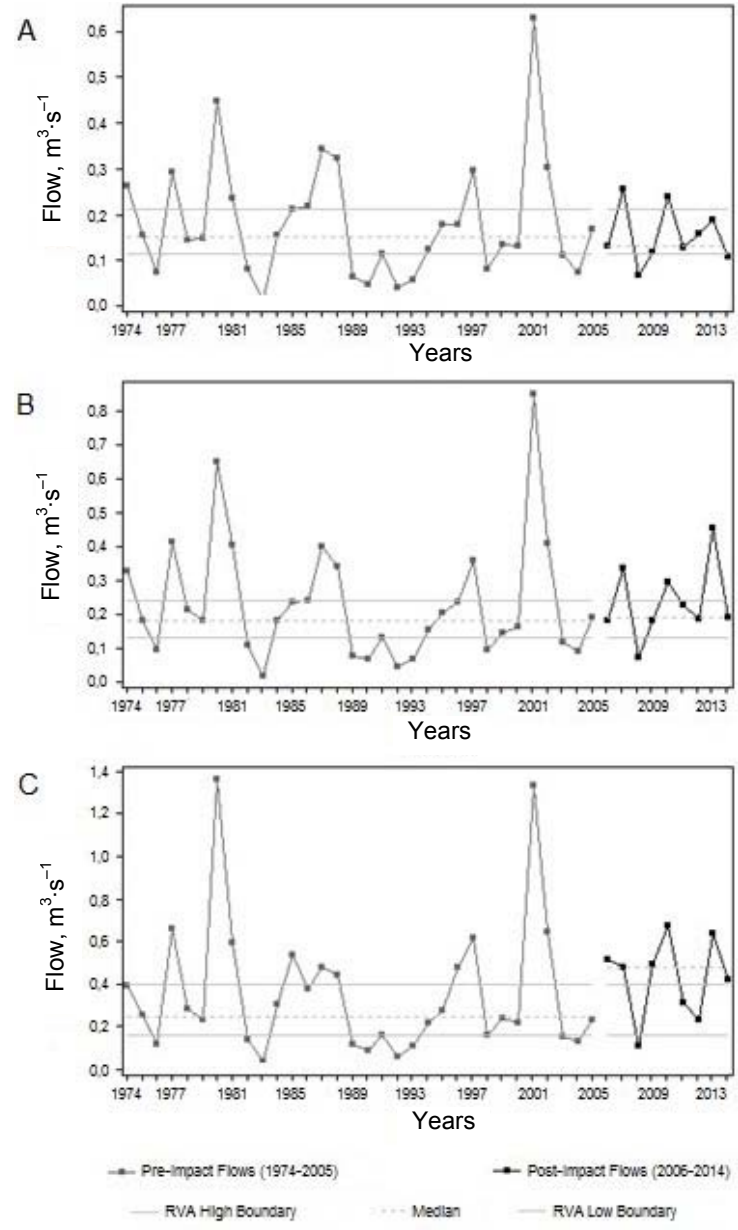

Fig. 4. The impact of the Stare Miasto reservoir on magnitude and duration of annual extreme water conditions: 7-day minimum (A), 30-day minimum (B), 90-day minimum (C); RVA as in Fig. 3; source: own study 
HA of 0.48 (Tab. 2). As shown in Figure 4C, the annual 90-day minimum flows at the Posoka gauge station increase approximately twice. In the post-impact period most of which are beyond the RVA high boundary with HA of -0.41 .

On the contrary median values of annual 1-, 3-, 7-, 30- and 90-day maximum flows are greater in post-impact period (Tab. 2). However they fall to the RVA target range with the same frequency with HA of 0.09 and 0.19 . The analysis of extreme values of 1-, 3-, 7-, 30- and 90-day minimal flows shows that after 2006 the minimal values are higher and maximal values are lower. Additionally the coefficients of dispersion of minimal flows are lower in the post dam construction period. The analysis depict that Stare Miasto has buffering effect on the river flows especially made the flow variability flatter. These results suggest that construction of reservoir enable to maintaing the flow, especially in dry seasons. The extreme value of maximal flows with duration from 1 to 90 day have the same tendency like the minimal flows, however in the post impact period the coefficients of variations are greater. The Stare Miasto reservoir have positive effect on flood control through the reduction of spring peak flows.

Group no. 3 includes IHA parameters which provide information about timing of annual extreme water conditions. The Julian date of 1-day minimum in the post-dam period is earlier for about 7 days than in pre-dam period. In IHA methods Julian date is the order number of day of the hydrological year. The Julian date of 1-day maximum in post-dam period is later for about 37 days. The HA values of these parameters reach 0.37 and -0.41 and they are assigned to moderate alteration class.

Parameters in group no. 4 characterize frequency and duration of high and low pulses. Medians of low and high pulse count are increased in post-dam period. In the case of low and high flow pulse duration a different results are obtained. Medians of these parameters are higher in pre-dam period. The HA values of low and high pulse count and high pulse duration show minimal alteration of $-0.05,-0.33$ and 0.09 respectively. Most of high pulse duration values after dam construction are below the low RVA boundary. After 2006, most of high pulse count values are above the high RVA boundary. The low pulse duration shows high alteration with HA of 0.78 (Fig. 5). This value fall more frequently within the RVA target range after 2006.

The last IHA group characterizes rate and frequency of water condition changes. It is noticed that medians values of rise and fall rate in the both of analyzed periods have not significantly changes. The medians of number of reversals are higher after 2006. In post-dam period, most values of this parameter are above the high RVA boundary. The HA values of all parameters in this IHA group show low alteration, $0.09,0.19,-0.11$ respectively.

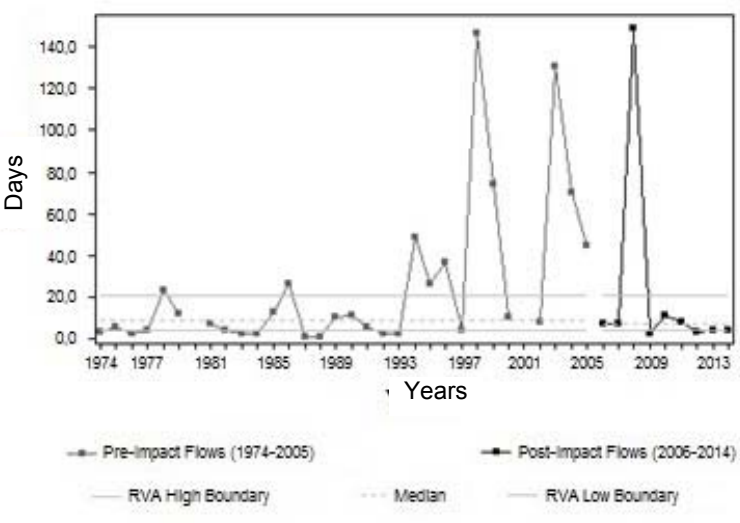

Fig. 5. The impact of the Stare Miasto reservoir on low pulse duration; RVA as in Figure 3; source: own study

\section{CONCLUSIONS}

1. The construction and operation of the Stare Miasto reservoir aimed to control of floods and providing water for irrigation, has a moderate impact on hydrological regime of the Powa River.

2. The high changes included significant decline of monthly median flows in April and May when the water are stored in reservoir. In June median monthly flows are slightly higher after dam construction however the great changes show coefficient of dispersion which is twice smaller.

3. The reservoir operations have positive effect on minimal flow stability which are important to preserve an natural habitat in a river.

4. The Stare Miasto reservoir reduces a spring peak flow and enables control of floods. However, the minimum of annual maximum flows after dam construction are higher.

5. To reduce minimize the ecological impacts, it is essential to analyze the existing operation rules and develop new reservoir management schemes with respect new hydroelectric function.

\section{Acknowledgements}

The daily hydrological data from 1984 to 2012 are provided by Institute of Meteorology and Water Management - National Research Institute. The basis for exchange of data is formal agreement signed between Institute and the Poznan University of Life Sciences about cooperation and support. This work is a part of a PhD dissertation MSc Joanna Jaskuła "The impact of reservoirs on physicochemical and morphological state of the lowland rivers".

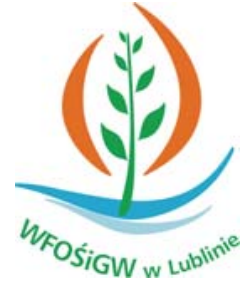

Dofinansowano ze środków Wojewódzkiego Funduszu Ochrony Środowiska i Gospodarki Wodnej w Lublinie Cofinanced by Voivodeship Fund for Environmental Protection and Water Management in Lublin 


\section{REFERENCES}

DYSARZ T., WiCHER-DYSARZ J. 2013. Analysis of flow conditions in the Stare Miasto Reservoir taking into account sediment settling properties. Rocznik Ochrona Środowiska. Vol. 15 p. 584-605.

Fantin-Cruz I., Pedrollo O., Girard P., Zeilhofer P., HAMILTON S.K. 2015. Effects of a diversion hydropower facility on the hydrological regime of the Correntes River, a tributary to the Pantanal floodplain, Brazil. Journal of Hydrology. Vol. 531 p. 810-820.

GRAF W.L. 1999. Dam nation: A geographic census of American dams and their large-scale hydrologic impacts. Water Resources Research. Vol. 35. Iss. 4 p. $1305-1311$.

GRAF W.L. 2001. Damage control: restoring the physical integrity of America's rivers. Annals of the Association of American Geographers. Vol. 91. Iss. 1 p. 1-27.

HARMAN C., SteWARDSON M. 2005. Optimizing dam release rules to meet environmental flow targets. River Research and Applications. Vol. 21. Iss. 2-3 p. 113-129.

Lajoie F., Assani A.A., Roy A., Mesfioui M. 2007. Impacts of dams on monthly flow characteristics. The influence of watershed size and seasons. Journal of Hydrology. Vol. 334. Iss. 3-4 p. 423-439.

MAGILLIGAN F.J., NisLOW K.H. 2001. Long-term changes in regional hydrologic regime following impoundment in a humid-climate watershed. Journal of the American Water Resources Association. Vol. 37. Iss. 6 p. 15511569.

Magilligan F. J., Nislow K.H. 2005. Changes in hydrologic regime by dams. Geomorphology. Vol. 71. Iss. 1 p. $61-78$.

POFF N.L., HaRT D.D. 2002. How dams vary and why it matters for the emerging science of dam removal. Bioscience. Vol. 52 p. 659-668.

Richter B.D., Baumgartner J.V., Braun D.P., Powell J. 1998. A spatial assessment of hydrologic alteration within a river network. Regulated Rivers: Research and Management. Vol. 14. Iss. 4 p. 329-340.
Richter B.D., Baumgartner J.V., Powell J., Braun D.P. 1996. A method for assessing hydrologic alteration within ecosystems. Conservation Biology. Vol. 10. Iss. 4 p. $1163-1174$.

Richter B., Baumgartner J., Wigington R., Braun D. 1997. How much water does a river need? Freshwater Biology. Vol. 37. Iss. 1 p. 231-249.

Rosenberg D.M., McCully P., Pringle C.M. 2000. Global-scale environmental effects of hydrological alterations: introduction. BioScience. Vol. 50. Iss. 9 p. 746 751.

STANFORD J.A., WARD J.V. 1993. An ecosystem perspective of alluvial rivers: connectivity and the hyporheic corridor. Journal of the North American Benthological Society. Vol. 12. Iss. 1 p. 48-60.

TebaKari T., Yoshitani J., SUVANPIMOL P. 2012. Impact of large scale reservoir operation on flow regime in the Chao Phraya River basin, Thailand. Hydrological Processes. Vol. 26. Iss. 16 p. 2411-2420.

The Nature Conservancy 2009. Indicators of hydrologic alteration version 7.1. - User's manual [online]. [Access 18.05.2016] Available at: https://www. conservationgateway.org/

WOLIŃSKI J., ZGRABCZYŃSKI J. 2008. Zbiornik retencyjny Stare Miasto na rzece Powie. Instrukcja gospodarowania woda [The Stare Miasto reservoir in the Powa River: Water management rules]. Poznań. „BIPROWODMEL" Sp. z o.o.

YAN, Y., YANG, Z., LiU, Q., Sun, T. 2010. Assessing effects of dam operation on flow regimes in the lower Yellow River. Procedia Environmental Sciences. Vol. 2 p. $507-$ 516.

Yu C., Yin X. A., YAng Z. 2015. A revised range of variability approach for the comprehensive assessment of the alteration of flow regime. Ecological Engineering. In press.

ZuO Q., LIANG S. 2015. Effects of dams on river flow regime based on IHA/RVA. International Association of Hydrological Sciences Publications. Vol. 368 p. 275280 .

\section{Mariusz SOJKA, Joanna JASKUŁA, Joanna WICHER-DYSARZ, Tomasz DYSARZ}

\section{Ocena wpływu zbiornika retencyjnego na zmianę reżimu hydrologicznego rzeki nizinnej - zbiornik Stare Miasto na rzece Powie}

\section{STRESZCZENIE}

Celem pracy była analiza i ocena wpływu zbiornika Stare Miasto na zmianę reżimu hydrologicznego rzeki Powy. Zbiornik został zbudowany w 2006 r. i zlokalizowany jest w centralnej części Polski. Powierzchnia zbiornika w normalnych warunkach piętrzenia wynosi 90,68 ha, a jego pojemność $2,159 \mathrm{mln}^{3}$. Do analizy zmian reżimu hydrologicznego rzeki Powy wykorzystano dane codziennych przepływów z wodowskazu Posoka z lat 1974-2014. Ocenę zmian hydrologicznych przeprowadzono z wykorzystaniem metody RVA (ang. Range of Viariability Approach). Obliczenia wykonano za pomoca oprogramowania IHA 7.1.0.10. Przeprowadzona analiza wykazała, że zbiornik Stare Miasto ma umiarkowany wpływ na reżim hydrologiczny rzeki Powy. Budowa zbiornika miała pozytywny wpływ na stabilizację przepływów minimalnych, które są istotne dla ochrony ekosystemów rzecznych. Uzyskane wyniki wskazują, że zbiornik Stare Miasto wpływa na złagodzenie fali przepływów maksymalnych i umożliwia umiarkowaną kontrolę powodzi.

Słowa kluczowe: IHA software, rezim hydrologiczny, zbiornik Stare Miasto 